\title{
GENDER RESEARCH IN AFRICA INTO ICTS FOR EMPOWERMENT (GRACE)
}

\author{
Panel
}

Ineke Buskens

GRACE, South Africa

Gertrudes Macueve

Eduardo Mondlane University, Mozambique

Ibou Sane

Dakar Sheikh Anta Diop University, Senegal \&

Gaston Berger de Saint Louis University, Senegal

Anne Webb

GRACE, Canada

This panel arises from a three-year research project (2005-2008) entitled Gender Research in Africa into ICTs for Empowerment ${ }^{71}$. The project, which is ongoing into a second phase, was undertaken to find out how and why women use ICTs and how the use (or non-use) affects their lives. This study engages with issues sometimes referred to as the gendered digital divide $[6,7,5]$, the recognition that men are participating and benefiting to a greater degree than women in the Information Society [9]. It is recognized that the gender divide is more than a matter of access and use of tools, or designing content. While there is "global agreement that gender equality is essential for building a "sustainable, just and developed society' [WSIS Declaration of Principles 2003]” [9, p. 135], there seems to be a gap in terms of understanding the implications of gender discrimination in relation to the potential benefits to society of the new technologies. This is a problem if societies as a whole are to benefit from ICTs and use them to further their development, if the vision of development pursued is to equitably reflect and fulfill the interests and needs of the population, not only those in positions of power.

The use of ICTs has the potential to enhance our lives and contribute to our wellbeing, effective use of time, economic development and so forth. Because they are merely tools whose meaning is defined by the use and the users, they can

\footnotetext{
${ }^{71}$ This project was funded by the International Development Research Centre of Canada. The views expressed in the paper are those of the authors, and do not necessarily represent the opinions of the funder. For more information on the GRACE project, please see our web site www.GRACENetwork.net.
}

Please use the following format when citing this chapter:

Buskens, I., Macueve, G., Sane, I. and Webb, A., 2008, in IFIP International Federation for Information Processing, Volume 282; Social Dimensions of Information and Communication Technology Policy; Chrisanthi Avgerou, Matthew L. Smith, Peter van den Besselaar; (Boston: Springer), pp. 363-367. 
also enhance gendered life situations, relationships and images and play thus a conservative, reactionary role. The GRACE project was undertaken to try to understand how women in Africa are engaging ICTs to improve their lives, and to try to understand when and how ICTs are beneficial to them and their pursuits, and when and why they are not.

\section{The GRACE project}

The GRACE project is unique on two levels: the subject matter of the research and the research coordination approach. The project explores the ways in which women in Africa use information and communication technologies (ICTs) to empower themselves. It focuses on the external, structural barriers women experience, as well as on the internal/conceptual factors which prevent or enable them to use ICTs to their advantage, and the strategies they use to overcome impediments [4].

The project comprises 14 sub-projects, reflecting 14 research sites in 12 countries in Africa. Approximately 30 researchers have been involved (women and men), with academic and NGO affiliations, supported by a coordination team.

The sub-projects differ from each other greatly in terms of target group and research focus, although they are all coherent with the general aim of the overall research initiative. Furthermore, the concepts of gender and empowerment which frame the project's general direction and commitment to women's equality do not have unequivocal meaning within the sub-projects. These concepts were understood and interpreted in various ways at the start of the project, and became increasingly multifaceted and contextualized through the duration of our work.

In terms of the research coordination approach, and the approaches taken by the researchers, emphasis was placed on the use of qualitative research techniques as these techniques yield in-depth data and are able to highlight the various dimensions and aspects of phenomena. The research questions and methodologies, the research trainings, as well as the ongoing mentoring and support program accompanying the research were grounded in the principles of critical emancipatory research $[1,3]$.

The methods used in each case were identified by the researchers as the best suited to learning about the lives and the thinking of their respondents. The respondents were approached as active agents in determining their own reality, rather than as victims of their situation. This may seem to contradict the point that women's lives are not well understood and are not setting development directions; however, we wanted to find out how women understood their current situations, we wanted them to think beyond their current realities, and to consider what needed to be in place for them to pursue their visions. To do this sort of reflection and thinking women had to see themselves as having the capacity for action on their own behalves $[1,2,3,8,11]$. It is this sort of thinking that produces practical, functional knowledge that can lead to change.

Another significant aspect of the research approach taken in GRACE is that the research teams conducted their research in their own contexts. They conducted 
their study either in their own region, their community, in their own workplace, or in some cases including themselves as respondents. While working in a familiar environment facilitates building rapport with research participants, and one's recognition of local specificities, researchers are faced with the task of also recognizing local norms for what they are - normalized social, cultural, gender, economic (and so forth) relations, not inevitables. Thus, as with an "outsider," a researcher working as a "native anthropologist" is also confronted with the task of revealing and questioning her own assumptions and biases, becoming aware of her own lenses [1], and managing to "'make strange that which appears familiar, and make familiar that which appears strange"" [2, 13a]. This condition of selfawareness or reflexivity is a key quality of the qualitative research approach engaged in the project.

\section{Panel presentations}

\section{Anne Webb/Ineke Buskens}

The panel moderators will open the session providing an introduction to the GRACE project as outlined above. They will introduce the research coordination approach and process engaged in the GRACE project and the significance of this approach. They will then introduce each of the panelists who will speak to their specific GRACE research project and the methods used, research context and analysis.

\section{Gertrudes Macueve}

"A number of studies suggest that information and communication technologies (ICTs) can contribute to empowering women. We selected two rural districts, Manhiça in the south and Sussundenga in central Mozambique, to investigate whether women in Mozambique's rural areas with access to ICTs through existing telecentres and the expanding mobile phone networks are becoming more empowered. Through qualitative research, we reached the conclusion that the main tools being used by women in these areas and playing an empowerment role are the community radio and the mobile phone, rather than ICTs such as computers, e-mail and Internet. The women are either unaware of the possibilities of the latter tools or do not find what is available sufficiently relevant to their immediate survival needs" [5].

\section{Ibou Sane}

"The massive movement of women into the popular and solidarity economy in Senegal reflects the state of the economic crisis that exerts great pressure on the fate of a large number of people affected by this situation aggravated by structural adjustment programmes implemented by the Bretton Woods international institutions. It is within this context that women's associations and women's 
promotion groups play key roles in mobilizing women to relax the economic and social constraints which weigh heavily on families. In this respect, women fishmongers and fish processors in Dakar intend, through entrepreneurship, to strengthen their creative capabilities in income-generating activities, and affirm their financial autonomy as a process of gradual questioning of the distribution system of the gendered social relationships. In this endeavour to conquer space for freedom and achievement, the mobile telephony as a working tool plays an important role in business transactions" [10].

\section{Panelists}

Ineke Buskens is a Cultural Anthropologist with a passion for research methodology and women's empowerment and a deep appreciation for cultural diversity and individual human uniqueness. Graduated in Leiden, the Netherlands, she has lived in Ghana, India, and Brazil and since 1990 she has lived in South Africa. After having been Head of the Centre for Research Methodology at South Africa's Human Science Research Council for 5 years, she founded Research for the Future in 1996. She works since as an independent international research and process facilitation consultant. In her research she focuses on emancipatory approaches that envision a sustainable, just and loving world, in her research training on bringing out the genius in every participant, in her facilitation work, on gender awareness and authentic collaboration. Ineke is a student of Ramtha's School of Enlightenment in Yelm, Washington, USA and this learning journey inspires her to become all she can be.

Gertrudes Macueve is a lecturer in computer sciences at Eduardo Mondlane University in Mozambique. She is currently doing her doctoral studies in the field of Information Systems. Her research interests include ICTs for development in general, and e-government and gender in particular. She has been involved in telecentre research activities since 2000, and was lead author for the Mozambique study.

Ibou Sane is a researcher and lecturer at the departments of sociology at Dakar Sheikh Anta Diop University and Gaston Berger de Saint Louis University (Senegal). He teaches urban sociology, political sociology, development sociology, informal sector sociology, sociology of associations' movement, methods of research on social science, assessment projects methods and sociological theories. His works focuses on the Senegalese commercial informal sector, on development, historical demography, and presently he is looking into gender, ICT and development.

Anne Webb's commitment to feminist qualitative research is rooted in participatory action research approaches. She has worked with communities and research teams for the past fifteen years pursuing the reduction of inequalities. Trained in sociology, adult education and gender studies in Toronto (Ontario Institute for Studies in Education) and Den Hague (Institute for Social Studies), her education has involved people from all walks of life and locations, formally 
and informally, in Canada, Europe, and Southern Africa, and is a continually enriching process. Anne currently resides in Hull, Quebec, Canada.

\section{References}

[1] Buskens, I. (2002). Fine lines or strong cords? Who do we think we are and how can we become what we want to be in the quest for quality in qualitative research?, Education as Change, 6 (1), 1-31.

[2] Buskens, I. (2006). Gender research in Africa into ICTs for empowerment, IICBA Newsletter UNESCO 8(2).

[3] Buskens, I \& Earl, S. (2008), Research for change - Outcome Mapping's contribution to emancipatory research in Africa, Action Research 6(2), 173-194.

[4] Buskens, I., Esterhuysen, A., \& Radloff, J. (2004). GRACE: Gender Research in Africa into ICTs for Empowerment, project proposal www.grace-network.net/publications/GRACE\%20proposal.pdf

[5] Gertrudes Macueve, G., Mandlate, J., Ginger, L., Gaster, P., \& Macome E. (2009, forthcoming). Women's use of ICTs in Manhiça and Sussundenga: A tool for empowerment? In Buskens, I. and A. Webb (Eds), Creating New Realities?, London: Zed Books.

[6] Hafkin J.N. (2000). Convergence of concepts: Gender and ICTs in Africa, in Gender and the Information Revolution in Africa, Ottawa: IDRC.

[7] Hafkin, J.N. \& S. Huyer. (2006). Cinderella or Cyberella? Empowering women in the knowledge society. Bloomfield: Kumarian.

[8] Hannan, C. (2004). Women's rights and empowerment: Gender equality in the new millennium, Presentation to the United Nations Day Banquet, Dallas Chapter of the United Nations, October 24.

[9] Huyer, S., Hafkin, J.N., Ertl, H., \& Dryburgh, H. (2005) Women in the information society in Sciadas, G. (ed.) From the Digital Divide to Digital Opportunities: Measuring Infostates for Development. Orbicom/ITU, Ottawa. http://www.orbicom.ca/media/projets/ddi2005/index_ict_opp.pdf, 134-194.

[10] Ibou Sane, I. \& M. Balla Traore. (2009, forthcoming). The mobile telephone as a tool for promotion of emancipation and strengthening of the entrepreneurial initiatives of women fish processors and wholesalers in Dakar. In Buskens, I. and A. Webb (Eds.), Creating New Realities?, London: Zed Books.

[11] Kabeer, N. (2003). Gender mainstreaming in poverty eradication and the Millennium Development Goals. Commonwealth Secretariat/IDRC/CIDA, Ottawa, p. 171.

[12] Rathgeber, E.M. (2000). Women, men, and ICTs in Africa: Why gender Is an issue in E.M. Rathgeber and E.O. Edera (Eds.) Gender and the Information Revolution in Africa, Ottawa: IDRC.

[13] Strega, Susan (2005). The view from the poststructural margins: Epistemology and methodology reconsidered. In L. Brown and S. Strega (Eds.) Research as resistance: critical, indigenous and anti-oppressive approaches. Toronto: Canadian Scholars Press.

a. Hekman 1999, p. 138 cited p. 231. 